\title{
Financial incentives and coverage of child health interventions: a systematic review and meta-analysis
}

Diego G Bassani ${ }^{1,2,3^{*}}$, Paul Arora², Kerri Wazny ${ }^{1}$, Michelle F Gaffey ${ }^{1,2}$, Lindsey Lenters ${ }^{1}$, Zulfiqar A Bhutta ${ }^{1,4}$

\begin{abstract}
Background: Financial incentives are widely used strategies to alleviate poverty, foster development, and improve health. Cash transfer programs, microcredit, user fee removal policies and voucher schemes that provide direct or indirect monetary incentives to households have been used for decades in Latin America, Sub-Saharan Africa, and more recently in Southeast Asia. Until now, no systematic review of the impact of financial incentives on coverage and uptake of health interventions targeting children under 5 years of age has been conducted. The objective of this review is to provide estimates on the effect of six types of financial incentive programs: (i) Unconditional cash transfers (CT), (ii) Conditional cash transfers (CCT), (iii) Microcredit (MC), (iv) Conditional Microcredit (CMC), (v) Voucher schemes (VS) and (vi) User fee removal (UFR) on the uptake and coverage of health interventions targeting children under the age of five years.
\end{abstract}

Methods: We conducted systematic searches of a series of databases until September 1st, 2012, to identify relevant studies reporting on the impact of financial incentives on coverage of health interventions and behaviors targeting children under 5 years of age. The quality of the studies was assessed using the CHERG criteria. Metaanalyses were undertaken to estimate the effect when multiple studies meeting our inclusion criteria were available.

Results: Our searches resulted in 1671 titles identified 25 studies reporting on the impact of financial incentive programs on 5 groups of coverage indicators: breastfeeding practices (breastfeeding incidence, proportion of children receiving colostrum and early initiation of breastfeeding, exclusive breastfeeding for six months and duration of breastfeeding); vaccination (coverage of full immunization, partial immunization and specific antigens); health care use (seeking healthcare when child was ill, visits to health facilities for preventive reasons, visits to health facilities for any reason, visits for health check-up including growth control); management of diarrhoeal disease (ORS use during diarrhea episode, continued feeding during diarrhea, healthcare during diarrhea episode) and other preventive health interventions (iron supplementation, vitamin A, zinc supplementation, preventive deworming). The quality of evidence on the effect of financial incentives on breastfeeding practices was low but seems to indicate a potential positive impact on receiving colostrum, early initiation of breastfeeding, exclusive breastfeeding and mean duration of exclusive breastfeeding. There is no effect of financial incentives on immunization coverage although there was moderate quality evidence of conditional cash transfers leading to a small but non-significant increase in coverage of age-appropriate immunization. There was low quality evidence of impact of CCT on healthcare use by children under age 5 (Risk difference: 0.14 [95\%Cl: 0.03; 0.26]) as well as low quality evidence of an effect of user fee removal on use of curative health services (RD=0.62 [0.41;0.82]).

Conclusions: Financial incentives may have potential to promote increased coverage of several important child health interventions, but the quality of evidence available is low. The more pronounced effects seem to be

\footnotetext{
* Correspondence: diego.bassani@sickkids.ca

${ }^{1}$ Centre for Global Child Health, The Hospital for Sick Children, Toronto, ON,

Canada

Full list of author information is available at the end of the article
}

\section{Ciomed Central}

C 2013 Bassani et al; licensee BioMed Central Ltd. This is an Open Access article distributed under the terms of the Creative Commons Attribution License (http://creativecommons.org/licenses/by/2.0), which permits unrestricted use, distribution, and reproduction in any medium, provided the original work is properly cited. 
achieved by programs that directly removed user fees for access to health services. Some indication of effect were
also observed for programs that conditioned financial incentives on participation in health education and
attendance to health care visits. This finding suggest that the measured effect may be less a consequence of the
financial incentive and more due to conditionalities addressing important informational barriers.

\section{Background}

Financial incentives are becoming widely used policy strategies to alleviate poverty, foster several aspects of development, and improve the health of populations. It has also been recommended as an important strategy to reduce barriers to access to health care [1] and, more often than not, health gains are explicit objectives of these strategies [2]. Microcredit [3-5], user fee removal policies [6], voucher schemes [7] and cash transfer programs [8-11] that provide direct or indirect monetary incentives to households, with or without activity or behavioral conditionalities, have been used for decades in Latin American [9,12-14] and sub-Saharan African countries [15-19], and in Southeast Asian settings [20-24].

With an overarching goal of poverty alleviation, and an assumption that, in general, these policies will allow market mechanisms to help people overcome poverty, many complex and expensive programs have been implemented on a very large scale in some countries [7,10,25-27]. More often than not there is an expectation that care, uptake and coverage of health interventions, and ultimately health status, will improve as a consequence of such programs and policies [18,24,28-30], as the poorest sections of the population most often face the greatest barriers to accessing health services [2]. In most instances, these are financial barriers [1]; hence, removing such impediments should lead to an increase in the uptake of health interventions and care seeking in case of illness. Evaluations of large programs have shown a doseresponse effect of the amount of money received on health status [14], suggesting it may act independently of the conditionality. In addition, many of these programs are conditional on school attendance $[9,12,31]$, participating in health education activities [32-34], taking children to preventive health-care visits $[9,25,31]$ and keeping vaccines up-to-date $[7,10,12,13,25]$, which should improve health status. Some other programs offer health education activities [22,33,34] or streamline participants' access to health care [26] in addition to the financial benefit offered, thereby addressing informational as well as financial barriers, but in many cases participation in such activities is not a condition for receiving the financial benefit.

Although previous systematic reviews and overviews [1,35-37] have addressed the impact of different types of financial incentive programs on health, no comprehensive systematic review has been conducted on the impact of a broad range of financial programs implemented in lowand middle-income countries on coverage and uptake of health interventions and behaviors targeting children under five years of age. The objective of this review is to provide estimates of the effect of six types of financial incentive programs on the uptake and coverage of such health interventions: (i) Unconditional cash transfers, (ii) Conditional cash transfers, (iii) Unconditional microcredit, (iv) Conditional microcredit, (v) Unconditional voucher (vi) Conditional voucher and (vi) User fee removal. These interventions are described in Table 1.

\section{Methods}

We systematically reviewed all studies published up to September 1st, 2012 to identify studies with data assessing the impact of financial incentives on access to child health interventions using the Child Health Evaluation Reference Group (CHERG) systematic review guidelines [38]. We conducted the initial search in March 2012 and updated searches on July 2012 and September 2012. The searches were completed using OvidSP to scan the Pubmed, EMBASE and AMED databases. We used all combinations of the following key search terms: Cash transfer, voucher scheme, demand side financing, social transfer, voucher program. We purposely included broad categories as well as names of financial schemes identified through previous reviews, other databases and repositories. We included in our search variations of names and/or acronyms of the thirty-five programs we identified in previous publications $[1,2,17,18,28$, $35,39-41]$. In addition, we searched variations of the terms microcredit, microfinance, micro-insurance, and economic empowerment, and limited the results of this search using variations of the terms evaluation or impact. To incorporate user fees, we adopted a previous review's search strategy [42], and limited to children. Our search strategies are described in detail in Additional File 1.

We included randomized controlled trials (RCT), cluster randomized controlled trials (cRCT) and observational studies reported either in peer-reviewed journals or in institutional or commissioned reports that assessed the impact of financial incentive programs on health interventions targeting children under the age of five. 
Table 1 Definitions of interventions included in the review

\begin{tabular}{|c|c|}
\hline Intervention & Definition \\
\hline $\begin{array}{l}\text { Unconditional Cash } \\
\text { Transfer }\end{array}$ & Monetary transfers to households or individuals without pre-imposed conditionalities. \\
\hline $\begin{array}{l}\text { Conditional Cash } \\
\text { Transfer }\end{array}$ & $\begin{array}{l}\text { Monetary transfers to households or individuals conditional on the recipient adopting and maintaining certain behaviors } \\
\text { prescribed by the cash transfer program. }\end{array}$ \\
\hline $\begin{array}{l}\text { Unconditional } \\
\text { Microcredit }\end{array}$ & $\begin{array}{l}\text { Small loans offered to borrowers (usually lacking employment or credit history) without imposing conditionalities other } \\
\text { than re-payment of the loaned amount. }\end{array}$ \\
\hline Conditional Microcredit & $\begin{array}{l}\text { Small loans offered to borrowers (usually lacking employment or credit history) conditional on the recipient adopting and } \\
\text { maintaining certain behaviors prescribed by the program in addition to re-payment of the loaned amount. }\end{array}$ \\
\hline $\begin{array}{l}\text { Unconditional } \\
\text { Voucher* }\end{array}$ & $\begin{array}{l}\text { Indirect monetary transfer given by issue of coupons, vouchers, electronic card transfer or other method used to purchase } \\
\text { commodities from local shops or outlets. }\end{array}$ \\
\hline Conditional Voucher & $\begin{array}{l}\text { Indirect monetary transfer given by issue of coupons, vouchers, electronic card transfer or other method used to purchase } \\
\text { commodities from local shops or outlets conditional on the recipient adopting and maintaining certain behaviors } \\
\text { prescribed by the voucher program. }\end{array}$ \\
\hline User Fee Removal & Total or nearly total (75\% or more) removal of user fees for accessing heath services. \\
\hline
\end{tabular}

* No unconditional voucher programs were included in this study.

\section{Types of outcomes reported}

Studies included in this review report on the impact of financial incentive programs on five groups of coverage indicators:

(a) Breastfeeding practices (breastfeeding incidence, feeding of colostrum, early initiation of breastfeeding, exclusive breastfeeding for 6 months and duration of breastfeeding);

(b) Vaccination (coverage of full vaccination, partial vaccination and specific vaccines);

(c) Health care use (preventive and curative health care use, visits to health facilities for preventive and curative reasons, visits to health facilities for check-up);

(d) Management of diarrheal diseases (ORS use, continued feeding and health care seeking);

(e) Other preventive health interventions (preventive deworming, vitamin A and iron supplementation).

A detailed description of the outcomes included in this review and the definitions used is presented in Table 2 .

We abstracted all available data in duplicate for each of the outcomes and financial incentives described above We presented effect measures as mean risk differences-in-difference and their 95\% confidence intervals. All analyses were done, using RevMan 5 (Cochrane Collaboration).

\section{Studies identified}

After removing duplicates, our searches yielded 1,567 titles. To ensure identification of all relevant literature, we scanned the references of all relevant articles identified through our searches. To complement our formal search strategy, we conducted a number of searches in Google Scholar. For these searches we used the names of identified conditional cash transfer, unconditional cash transfer, voucher-scheme, microfinance and food stamp programs combined with the terms evaluation and health and the country in which the program was carried out. Results were sorted by relevance and the titles and abstracts of the articles in the first ten pages of results were scanned for inclusion. In cases where titles and abstracts were not in English, titles and abstracts were translated using Google Translate. In cases where search results were obviously irrelevant, titles and abstracts were only scanned for the first five pages of results. Articles that had previously been found through the formal search strategy were not pulled again. A total of 78 Google Scholar searches were performed, in which 99 articles were identified as satisfying initial inclusion criteria. We also searched the Microfinance Gateway library and screened all publications relating to the terms health and nutrition. Of the 1,666 screened in duplicate based on titles and abstracts, 1,527 articles were excluded as obviously irrelevant. We thoroughly reviewed 139 full publications identified through our searches as well as an additional five articles that were located through scanning references of relevant articles, also in duplicate. We excluded 119 of these articles based on criteria defined a priori, either because they contained duplicate data to one of our included studies, did not include an eligible financial intervention, did not have a comparison group or relevant outcomes. In the end, 25 studies were included $[7,8,10,15,16$, $21-23,25,26,33,34,40,42-53]$. Figure 1 is a schematic representation of our search.

\section{Results}

\section{Types of reports}

Just under half the studies were institutional reports and thus were not peer-reviewed $[8,10,25,33,34,43,45,47-50]$. Only $36 \%$ of the studies were randomized trials. Of the 25 studies, 13 were in South America or the Caribbean $[7,8,10,25,26,34,43-45,47-49,51], 8$ were in Africa $[15,16,33,40,42,50,52,53]$ and 4 were in South East Asia 


\section{Table 2 Definitions of outcomes included in the review and effect measure reported}

\begin{tabular}{|c|c|c|}
\hline Outcome & Definition & Effect measure* \\
\hline \multicolumn{3}{|c|}{ Breastfeeding practices } \\
\hline $\begin{array}{l}\text { Receiving } \\
\text { colostrum }\end{array}$ & Percentage of newborns receiving colostrum & $\begin{array}{l}\text { Mean difference in the change in percentage of newborns } \\
\text { receiving colostrum between intervention and control group }\end{array}$ \\
\hline $\begin{array}{l}\text { Early initiation of } \\
\text { breastfeeding }\end{array}$ & $\begin{array}{l}\text { Percentage of newborns breastfed within the first hour } \\
\text { of life }\end{array}$ & $\begin{array}{l}\text { Mean difference in the change in percentage of early initiation of } \\
\text { breastfeeding between intervention and control group }\end{array}$ \\
\hline $\begin{array}{l}\text { Exclusive } \\
\text { breastfeeding }\end{array}$ & $\begin{array}{l}\text { Percentage of infants } 0 \text { to } 5 \text { months who are exclusively } \\
\text { breastfed }\end{array}$ & $\begin{array}{l}\text { Mean difference in the change in percentage of exclusive } \\
\text { breastfeeding between intervention and control group }\end{array}$ \\
\hline $\begin{array}{l}\text { Duration of } \\
\text { exclusive } \\
\text { breastfeeding }\end{array}$ & Mean duration of exclusive breasfeeding in days & $\begin{array}{l}\text { Mean difference in the percent change in duration of exclusive } \\
\text { breastfeeding between intervention and control group }\end{array}$ \\
\hline $\begin{array}{l}\text { Breastfeeding } \\
\text { among children } \\
<2 \text { years }\end{array}$ & $\begin{array}{l}\text { Percentage of children under } 2 \text { years of age that are or } \\
\text { were breastfed }\end{array}$ & $\begin{array}{l}\text { Mean difference in the change in percentage of any breastfeeding } \\
\text { between intervention and control group }\end{array}$ \\
\hline \multicolumn{3}{|l|}{ Vaccination } \\
\hline BCG coverage & Percentage of children that received BCG & $\begin{array}{l}\text { Mean difference in the change in BCG coverage between } \\
\text { intervention and control group }\end{array}$ \\
\hline DPT-1 coverage & Percentage of children that received DPT-1 vaccine & $\begin{array}{l}\text { Mean difference in the change in DPT-1 coverage between } \\
\text { intervention and control group }\end{array}$ \\
\hline DPT-3 coverage & Percentage of children that received DPT-3 vaccine & $\begin{array}{l}\text { Mean difference in the change in DPT-3 coverage between } \\
\text { intervention and control group }\end{array}$ \\
\hline MCV coverage & $\begin{array}{l}\text { Percentage of children that received measles (MCV) } \\
\text { vaccine }\end{array}$ & $\begin{array}{l}\text { Mean difference in the change in MCV coverage between } \\
\text { intervention and control group }\end{array}$ \\
\hline $\begin{array}{l}\text { Polio vaccine } \\
\text { coverage }\end{array}$ & Percentage of children that received polio vaccine & $\begin{array}{l}\text { Mean difference in the change in OPV coverage between } \\
\text { intervention and control group }\end{array}$ \\
\hline $\begin{array}{l}\text { Any vaccination } \\
\text { coverage }\end{array}$ & Percentage of children that received any vaccine & $\begin{array}{l}\text { Mean difference in the change in coverage of any antigen } \\
\text { between intervention and control group }\end{array}$ \\
\hline $\begin{array}{l}\text { Full vaccination } \\
\text { coverage }\end{array}$ & $\begin{array}{l}\text { Percentage of children that are fully vaccinated } \\
\text { according to the country's EPI schedule for their age }\end{array}$ & $\begin{array}{l}\text { Mean difference in the change in coverage of EPI between } \\
\text { intervention and control group }\end{array}$ \\
\hline \multicolumn{3}{|l|}{ Health care use } \\
\hline $\begin{array}{l}\text { Preventive health } \\
\text { care use }\end{array}$ & $\begin{array}{l}\text { Percentage of children with a preventive health care visit } \\
\text { in the previous } 6 \text { months** }\end{array}$ & $\begin{array}{l}\text { Mean difference in the change in the percentage of children } \\
\text { reporting a preventive health care visit between intervention and } \\
\text { control group }\end{array}$ \\
\hline $\begin{array}{l}\text { Curative health care } \\
\text { use }\end{array}$ & $\begin{array}{l}\text { Percentage of children with a health care visit due to } \\
\text { illness in the previous } 6 \text { months** }\end{array}$ & $\begin{array}{l}\text { Mean difference in the change in the percentage of children } \\
\text { reporting a curative health care visit between intervention and } \\
\text { control group }\end{array}$ \\
\hline Health care use & $\begin{array}{l}\text { Percentage of children with any health care visit in the } \\
\text { previous } 6 \text { months** }\end{array}$ & $\begin{array}{l}\text { Mean difference in the change in the percentage of children reporting } \\
\text { any health facility visit between intervention and control group }\end{array}$ \\
\hline $\begin{array}{l}\text { Preventive health } \\
\text { care visits }\end{array}$ & $\begin{array}{l}\text { Mean number of child-visits for preventive reasons in the } \\
\text { previous month** }\end{array}$ & $\begin{array}{l}\text { Mean difference in the percentage change in the number of } \\
\text { preventive visits between intervention and control group }\end{array}$ \\
\hline $\begin{array}{l}\text { Curative health care } \\
\text { visits }\end{array}$ & $\begin{array}{l}\text { Mean number of child-visits due to illness in the } \\
\text { previous month** }\end{array}$ & $\begin{array}{l}\text { Mean difference in the percentage change in the number of } \\
\text { curative visits between intervention and control group }\end{array}$ \\
\hline $\begin{array}{l}\text { New health care } \\
\text { visits }\end{array}$ & $\begin{array}{l}\text { Mean number of new child-visits in the previous } \\
\text { month }^{* *}\end{array}$ & $\begin{array}{l}\text { Mean difference in the percentage change in the number of new } \\
\text { visits between intervention and control group }\end{array}$ \\
\hline $\begin{array}{l}\text { Follow-up health } \\
\text { care visits }\end{array}$ & $\begin{array}{l}\text { Mean number of follow-up child-visits after a curative } \\
\text { visit in the previous month** }\end{array}$ & $\begin{array}{l}\text { Mean difference in the percentage change in the number of } \\
\text { follow-up visits between intervention and control group }\end{array}$ \\
\hline Health care visits & Mean number of any child-visit in the previous month** & $\begin{array}{l}\text { Mean difference in the percentage change in the number of any } \\
\text { visits between intervention and control group }\end{array}$ \\
\hline \multicolumn{3}{|c|}{ Management of diarrhoeal disease } \\
\hline ORS use & $\begin{array}{l}\text { Percentage of children that received oral rehydration } \\
\text { solution during the last episode of diarrhoea }\end{array}$ & $\begin{array}{l}\text { Mean difference in the change in percentage of ORS use during } \\
\text { latest diarrhoea episode between intervention and control group }\end{array}$ \\
\hline Continued feeding & $\begin{array}{l}\text { Percentage of children that were fed the same amount } \\
\text { or more than usual during the last episode of diarrhoea }\end{array}$ & $\begin{array}{l}\text { Mean difference in the change in percentage of continued feeding } \\
\text { during latest diarrhoea episode between intervention and control } \\
\text { group }\end{array}$ \\
\hline Care-seeking & $\begin{array}{l}\text { Percentage of children that were taken to a health } \\
\text { facility during the last episode of diarrhoea }\end{array}$ & $\begin{array}{l}\text { Mean difference in the change in the percentage of children taken } \\
\text { to health facility during latest diarrhoea episode between } \\
\text { intervention and control group }\end{array}$ \\
\hline
\end{tabular}


Table 2 Definitions of outcomes included in the review and effect measure reported (Continued)

\begin{tabular}{|c|c|c|}
\hline \multicolumn{3}{|c|}{ Other preventive health interventions } \\
\hline $\begin{array}{l}\text { Preventive } \\
\text { deworming }\end{array}$ & $\begin{array}{l}\text { Percentage of children that received deworming } \\
\text { drugs in the last } 6 \text { months** }\end{array}$ & $\begin{array}{l}\text { Mean difference in the change in percentage of preventive } \\
\text { deworming between intervention and control group }\end{array}$ \\
\hline $\begin{array}{l}\text { Vitamin A } \\
\text { supplementation }\end{array}$ & $\begin{array}{l}\text { Percentage of children that received Vitamin A } \\
\text { supplementation in the last } 6 \text { months }{ }^{* *}\end{array}$ & $\begin{array}{l}\text { Mean difference in the change in percentage of vitamin A } \\
\text { supplementation between intervention and control group }\end{array}$ \\
\hline $\begin{array}{l}\text { Iron } \\
\text { supplementation }\end{array}$ & $\begin{array}{l}\text { Percentage of children that received iron } \\
\text { supplementation in the last } 6 \text { months** }\end{array}$ & $\begin{array}{l}\text { Mean difference in the change in percentage of iron } \\
\text { supplementation between intervention and control group }\end{array}$ \\
\hline
\end{tabular}

* In the case of cross-sectional studies, the effect measure was calculated assuming no change in control group and that the baseline value for the intervention group as equal to that of the control group.

** When reporting period is different this is noted as a limitation in the quality assessment table.

[21-23,46]. $48 \%$ of the studies evaluated cash transfer programs: $41 \%$ evaluated conditional cash transfer programs and $7 \%$ evaluated unconditional cash transfer programs. $22 \%$ of the programs evaluated the effects of removing user fees. One quarter of the studies evaluated microcredit programs. Almost half of the programs evaluated $(48 \%)$ had a conditional component relating to health. For details of each study, see Additional file 2 . We present forest plots only for selected outcomes. Additional file 3 presents forest plots for all study outcomes.

\section{Evidence of effect of financial incentives on breastfeeding} practices

The overall quality of evidence for the effect of financial incentives on breastfeeding practices was low, mainly due to the limited number of relevant studies available (Table 3 ). The pooled estimate from two studies suggests that conditional microcredit programs produce an average $22 \%$ net increase in the percentage of newborns receiving colostrum (MD=0.22; CI: 0.08 to 0.35 ) compared to control (Figure 2). Evidence from another two microcredit studies suggests no statistically significant effect of either

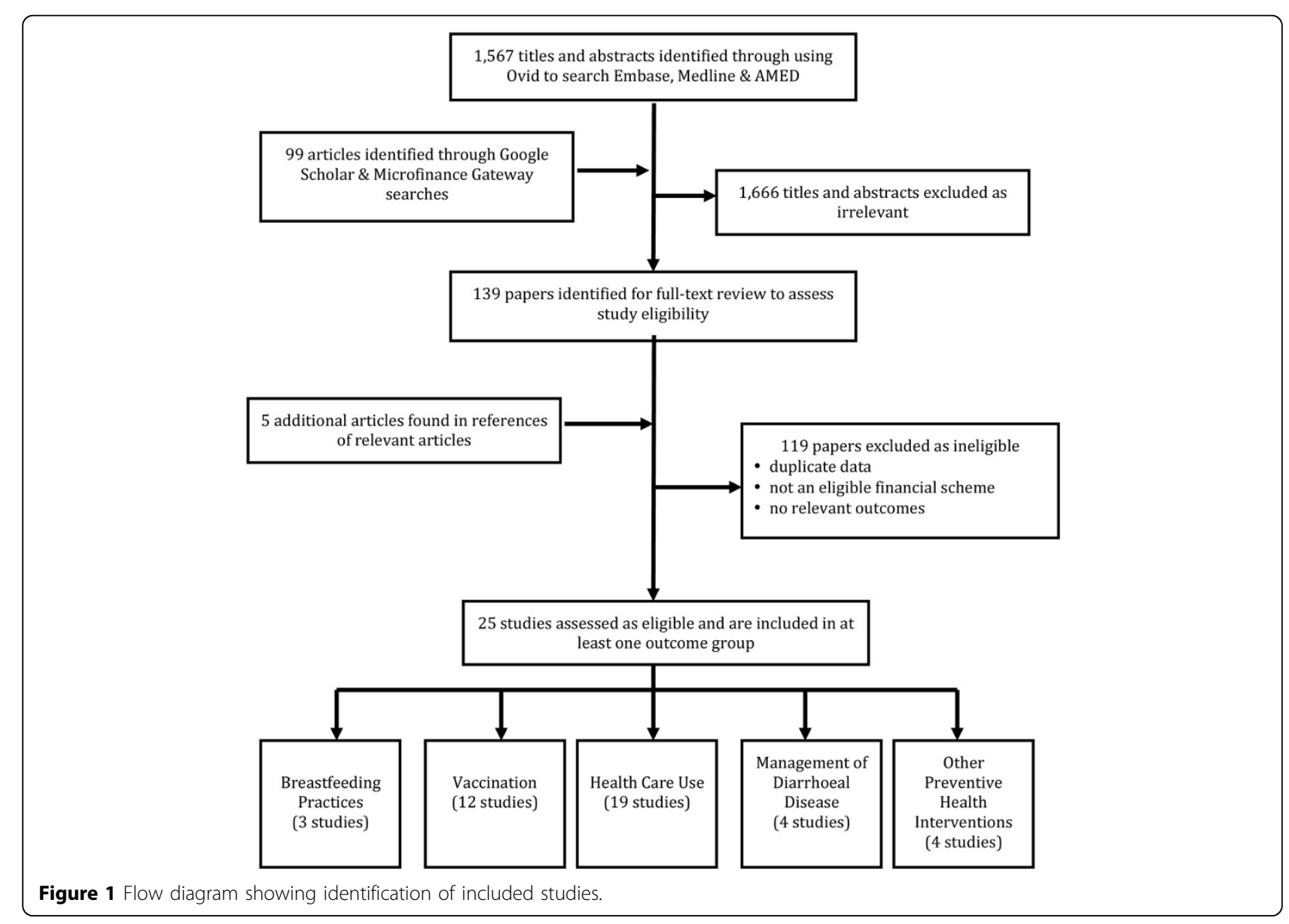


Table 3 Quality assessment of effect estimates of financial incentives on coverage of breastfeeding practices

\begin{tabular}{|c|c|c|c|c|c|c|c|c|}
\hline Intervention & $\begin{array}{l}\text { No. of } \\
\text { studies }\end{array}$ & Design & Limitations & Consistency & $\begin{array}{c}\text { Generalizability } \\
\text { to population } \\
\text { of interest }\end{array}$ & $\begin{array}{l}\text { Conditionalities } \\
\text { related to outcome } \\
\text { (no. of studies) }\end{array}$ & $\begin{array}{c}\text { Overall } \\
\text { quality of } \\
\text { evidence }\end{array}$ & $\begin{array}{c}\text { Mean } \\
\text { difference } \\
(95 \% \mathrm{Cl})\end{array}$ \\
\hline \multicolumn{9}{|c|}{ Receiving colostrum } \\
\hline $\begin{array}{l}\text { Conditional } \\
\text { microcredit }\end{array}$ & 2 & $\begin{array}{l}\text { Cluster } \\
\text { RCT } \\
\text { /Cohort }\end{array}$ & $\begin{array}{c}\text { Analysis of } C R C T \text { does } \\
\text { not account for } \\
\text { clustering }\end{array}$ & $\begin{array}{l}\text { Consistent and } \\
\text { both studies } \\
\text { show benefit }\end{array}$ & $\begin{array}{l}\text { Bolivia and } \\
\text { Ghana }\end{array}$ & $\begin{array}{l}\text { Health and nutrition } \\
\text { education (2) }\end{array}$ & Low & $\begin{array}{l}0.22(0.08 ; \\
0.35)\end{array}$ \\
\hline \multicolumn{9}{|c|}{ Early initiation of breastfeeding } \\
\hline $\begin{array}{l}\text { Conditional } \\
\text { microcredit }\end{array}$ & 1 & $\begin{array}{l}\text { Cluster } \\
\text { RCT }\end{array}$ & $\begin{array}{l}\text { Single study. Analysis of } \\
\text { CRCT does not account } \\
\text { for clustering }\end{array}$ & - & Bolivia & $\begin{array}{l}\text { Health and nutrition } \\
\text { education (1) }\end{array}$ & Low & $\begin{array}{l}0.17(0.01 \\
0.33)\end{array}$ \\
\hline \multicolumn{9}{|c|}{ Exclusive breastfeeding } \\
\hline $\begin{array}{l}\text { Conditional } \\
\text { microcredit }\end{array}$ & 1 & $\begin{array}{l}\text { Cluster } \\
\text { RCT }\end{array}$ & $\begin{array}{l}\text { Single study. Analysis of } \\
\text { CRCT does not account } \\
\text { for clustering }\end{array}$ & - & Bolivia & $\begin{array}{l}\text { Health and nutrition } \\
\text { education (1) }\end{array}$ & Low & $\begin{array}{l}0.20(0.03 ; \\
0.37)\end{array}$ \\
\hline \multicolumn{9}{|c|}{ Duration of exclusive breastfeeding } \\
\hline $\begin{array}{l}\text { Conditional } \\
\text { microcredit }\end{array}$ & 1 & Cohort & Only one study & - & Ghana & $\begin{array}{l}\text { Health and nutrition } \\
\text { education (1) }\end{array}$ & Low & $\begin{array}{c}11.49(1.69 ; \\
21.29)\end{array}$ \\
\hline \multicolumn{9}{|c|}{ Breastfeeding among children $<2$ years } \\
\hline $\begin{array}{l}\text { Unconditional } \\
\text { microcredit }\end{array}$ & 2 & Cohort & $\begin{array}{c}\text { Type of breastfeeding (e. } \\
\text { g. exclusive, } \\
\text { predominant) is not } \\
\text { specified }\end{array}$ & $\begin{array}{l}\text { Consistent, both } \\
\text { studies show } \\
\text { negative effect }\end{array}$ & $\begin{array}{c}\text { Ecuador and } \\
\text { Honduras }\end{array}$ & - & Low & $\begin{array}{c}-0.06(-0.16 \\
0.04)\end{array}$ \\
\hline $\begin{array}{l}\text { Conditional } \\
\text { microcredit }\end{array}$ & 2 & Cohort & $\begin{array}{c}\text { Type of breastfeeding (e. } \\
\text { g. exclusive, } \\
\text { predominant) is not } \\
\text { specified }\end{array}$ & Inconsistent & $\begin{array}{l}\text { Ecuador and } \\
\text { Honduras }\end{array}$ & $\begin{array}{l}\text { Health and nutrition } \\
\text { education (2) }\end{array}$ & Low & $\begin{array}{c}-0.01(-0.03 ; \\
\quad 0.02)\end{array}$ \\
\hline
\end{tabular}

conditional (MD=-0.01; CI: -0.03 to 0.02$)$ or unconditional (MD=-0.06; CI: -0.16 to 0.04 ) microcredit programs on the prevalence of any breastfeeding among children under two years (Table 3). Estimates of the effect of financial incentive programs on early initiation of breastfeeding and the prevalence and duration of exclusive breastfeeding (measured in months) among children under six months are based on single studies that were published as non-peer-reviewed reports. In four of the six studies included in these analyses of breastfeeding practices, the financial incentives were conditional on mothers' participation in health and nutrition education sessions that included breastfeeding promotion.

Evidence of effect of financial incentives on immunization There is moderate or low quality evidence from conditional cash transfer and conditional microcredit programs indicating no significant effect of either of these types of financial incentive on the coverage of BCG, DPT-1, DPT-3, measles or polio vaccination or on the coverage of any vaccination (Table 4 ). Financial incentives in many of the studies included in these analyses

\begin{tabular}{|c|c|c|c|c|c|c|c|}
\hline Study or Subgroup & Mean Difference & SE & Weight & $\begin{array}{l}\text { Mean Difference } \\
\text { IV, Random, } 95 \% \mathrm{CI}\end{array}$ & \multicolumn{3}{|c|}{$\begin{array}{c}\text { Mean Difference } \\
\text { IV, Random, } 95 \% \mathrm{CI}\end{array}$} \\
\hline \multicolumn{8}{|c|}{ 1.1.1 Conditional Microcredit } \\
\hline MkNelly 1998 & 0.28 & 0.0487 & $54.3 \%$ & $0.28[0.18,0.38]$ & & & \\
\hline $\begin{array}{l}\text { MkNelly } 1999 \\
\text { Subtotal }(95 \% \mathrm{CI})\end{array}$ & 0.14 & 0.0638 & $\begin{array}{r}45.7 \% \\
100.0 \%\end{array}$ & $\begin{array}{r}0.14[0.01,0.27] \\
0.22[0.08,0.35]\end{array}$ & & & \\
\hline \multicolumn{8}{|c|}{$\begin{array}{l}\text { Heterogeneity: } \text { Tau }^{2}=0.01 ; \mathrm{Chi}^{2}=3.04, \mathrm{df}=1(P=0.08) ; \mathrm{I}^{2}=67 \% \\
\text { Test for overall effect: } \mathrm{Z}=3.10(P=0.002)\end{array}$} \\
\hline & & & & & -0.5 & $\begin{array}{c}-0.25 \\
\text { Favours control }\end{array}$ & $\begin{array}{cr}0.25 & 0.5 \\
\text { Favours experimental }\end{array}$ \\
\hline
\end{tabular}


Table 4 Quality assessment of effect estimates of financial incentives on coverage of child vaccination

\begin{tabular}{|c|c|c|c|c|c|c|c|c|}
\hline Intervention & $\begin{array}{l}\text { No. of } \\
\text { studies }\end{array}$ & Design & Limitations & Consistency & $\begin{array}{l}\text { Generalizability } \\
\text { to population } \\
\text { of interest }\end{array}$ & $\begin{array}{l}\text { Conditionalities } \\
\text { related to } \\
\text { outcome (no. } \\
\text { of studies) }\end{array}$ & $\begin{array}{c}\text { Overall } \\
\text { quality } \\
\text { of } \\
\text { evidence }\end{array}$ & $\begin{array}{c}\text { Mean } \\
\text { difference } \\
(95 \% \mathrm{Cl})\end{array}$ \\
\hline \multicolumn{9}{|c|}{ BCG coverage } \\
\hline $\begin{array}{l}\text { Conditional } \\
\text { cash transfer }\end{array}$ & 3 & $\begin{array}{l}\text { RCT/Cluster } \\
\text { RCT/Cohort }\end{array}$ & $\begin{array}{l}>20 \% \text { attrition in cohort } \\
\text { study and not peer- } \\
\text { reviewed }\end{array}$ & Inconsistent & $\begin{array}{l}\text { Bangladesh, } \\
\text { Jamaica and } \\
\text { Nicaragua }\end{array}$ & $\begin{array}{l}\text { Preventive health } \\
\text { visits (2) }\end{array}$ & Moderate & $\begin{array}{l}0.00(-0.04 ; \\
0.04)\end{array}$ \\
\hline $\begin{array}{l}\text { Conditional } \\
\text { microcredit }\end{array}$ & 2 & $\begin{array}{l}\text { Cluster RCT/ } \\
\text { Cohort }\end{array}$ & $\begin{array}{l}\text { Analysis of CRCT does not } \\
\text { account for clustering. }\end{array}$ & $\begin{array}{l}\text { Consistent, } \\
\text { both studies } \\
\text { show benefit }\end{array}$ & $\begin{array}{l}\text { Bolivia and } \\
\text { Ghana }\end{array}$ & $\begin{array}{l}\text { Preventive health } \\
\text { visits (1) }\end{array}$ & Low & $\begin{array}{l}0.09(-0.02 ; \\
0.20)\end{array}$ \\
\hline \multicolumn{9}{|c|}{ DPT-1 coverage } \\
\hline $\begin{array}{l}\text { Conditional } \\
\text { cash transfer }\end{array}$ & 2 & $\begin{array}{l}\text { RCT/Cross- } \\
\text { sectional }\end{array}$ & $\begin{array}{l}\text { Reverse causality possible } \\
\text { in one study which is } \\
\text { also not peer-reviewed }\end{array}$ & Inconsistent & $\begin{array}{l}\text { Bangladesh and } \\
\text { Colombia }\end{array}$ & $\begin{array}{l}\text { Preventive health } \\
\text { visits (1) }\end{array}$ & Low & $\begin{array}{l}0.06(-0.01 ; \\
0.12)\end{array}$ \\
\hline $\begin{array}{l}\text { Unconditional } \\
\text { microcredit }\end{array}$ & 1 & Cross-sectional & Only one study & - & Bangladesh & - & Low & $\begin{array}{l}-0.02(-0.19 ; \\
0.15)\end{array}$ \\
\hline $\begin{array}{l}\text { Conditional } \\
\text { microcredit }\end{array}$ & 2 & $\begin{array}{l}\text { Cluster RCT/ } \\
\text { Cohort }\end{array}$ & $\begin{array}{l}\text { Analysis of CRCT does not } \\
\text { account for clustering. }\end{array}$ & Inconsistent & $\begin{array}{l}\text { Bolivia and } \\
\text { Ghana }\end{array}$ & $\begin{array}{l}\text { Health education } \\
\text { (2) }\end{array}$ & Low & $\begin{array}{l}-0.02(-0.23 ; \\
\quad 0.19)\end{array}$ \\
\hline $\begin{array}{c}\text { Conditional } \\
\text { voucher }\end{array}$ & 1 & Cluster RCT & Only one study & - & Honduras & $\begin{array}{l}\text { Preventive health } \\
\text { visits (1) }\end{array}$ & Low & $\begin{array}{l}0.07(0.01 ; \\
0.13)\end{array}$ \\
\hline \multicolumn{9}{|c|}{ DPT-3 coverage } \\
\hline $\begin{array}{l}\text { Conditional } \\
\text { cash transfer }\end{array}$ & 3 & $\begin{array}{l}\text { RCT/Cluster } \\
\text { RCT/Cohort }\end{array}$ & $\begin{array}{l}>20 \% \text { attrition in cohort } \\
\text { study and not peer- } \\
\text { reviewed }\end{array}$ & Inconsistent & $\begin{array}{l}\text { Bangladesh, } \\
\text { Jamaica and } \\
\text { Nicaragua }\end{array}$ & $\begin{array}{l}\text { Preventive health } \\
\text { visits (2) }\end{array}$ & Moderate & $\begin{array}{l}0.01(-0.03 ; \\
0.06)\end{array}$ \\
\hline $\begin{array}{l}\text { Conditional } \\
\text { microcredit }\end{array}$ & 2 & $\begin{array}{c}\text { Cluster RCT/ } \\
\text { Cohort }\end{array}$ & $\begin{array}{l}\text { Analysis of CRCT does not } \\
\text { account for clustering. }\end{array}$ & Inconsistent & $\begin{array}{l}\text { Bolivia and } \\
\text { Ghana }\end{array}$ & $\begin{array}{l}\text { Health education } \\
\text { (2) }\end{array}$ & Low & $\begin{array}{l}0.03(-0.20 ; \\
0.27)\end{array}$ \\
\hline \multicolumn{9}{|c|}{ MVC coverage } \\
\hline $\begin{array}{l}\text { Conditional } \\
\text { cash transfer }\end{array}$ & 3 & $\begin{array}{l}\text { RCT/Cluster } \\
\text { RCT/Cohort }\end{array}$ & $\begin{array}{l}>20 \% \text { attrition in cohort } \\
\text { study and not peer- } \\
\text { reviewed }\end{array}$ & Inconsistent & $\begin{array}{l}\text { Bangladesh, } \\
\text { Jamaica and } \\
\text { Nicaragua }\end{array}$ & $\begin{array}{l}\text { Preventive health } \\
\text { visits (2) }\end{array}$ & Moderate & $\begin{array}{c}-0.01(-0.11 ; \\
0.09)\end{array}$ \\
\hline $\begin{array}{l}\text { Unconditional } \\
\text { microcredit }\end{array}$ & 1 & Cross-sectional & Only one study & - & Bangladesh & - & Low & $\begin{array}{l}0.09(0.08 ; \\
0.11)\end{array}$ \\
\hline $\begin{array}{l}\text { Conditional } \\
\text { microcredit }\end{array}$ & 2 & $\begin{array}{l}\text { Cluster RCT/ } \\
\text { Cohort }\end{array}$ & $\begin{array}{l}\text { Analysis of } C R C T \text { does not } \\
\text { account for clustering }\end{array}$ & Inconsistent & $\begin{array}{l}\text { Bolivia and } \\
\text { Ghana }\end{array}$ & $\begin{array}{l}\text { Health education } \\
\text { (2) }\end{array}$ & Low & $\begin{array}{c}-0.04(-0.46 ; \\
0.38)\end{array}$ \\
\hline $\begin{array}{l}\text { Conditional } \\
\text { voucher }\end{array}$ & 1 & Cluster RCT & Only one study & - & Honduras & $\begin{array}{l}\text { Preventive health } \\
\text { visits (1) }\end{array}$ & Low & $\begin{array}{l}0.00(-0.09 ; \\
0.09)\end{array}$ \\
\hline \multicolumn{9}{|c|}{ OPV-3 coverage } \\
\hline $\begin{array}{l}\text { Conditional } \\
\text { cash transfer }\end{array}$ & 3 & $\begin{array}{l}\text { RCT/Cluster } \\
\text { RCT /Cohort }\end{array}$ & $\begin{array}{l}>20 \% \text { attrition in cohort } \\
\text { study and not peer- } \\
\text { reviewed }\end{array}$ & Inconsistent & $\begin{array}{l}\text { Bangladesh, } \\
\text { Jamaica and } \\
\text { Nicaragua }\end{array}$ & $\begin{array}{l}\text { Preventive health } \\
\text { visits (2) }\end{array}$ & Moderate & $\begin{array}{l}0.03(-0.04 ; \\
0.11)\end{array}$ \\
\hline $\begin{array}{l}\text { Conditional } \\
\text { microcredit }\end{array}$ & 2 & $\begin{array}{l}\text { Cluster RCT/ } \\
\text { Cohort }\end{array}$ & $\begin{array}{l}\text { Analysis of CRCT does not } \\
\text { account for clustering }\end{array}$ & $\begin{array}{c}\text { Consistent, } \\
\text { both studies } \\
\text { show negative } \\
\text { effect }\end{array}$ & $\begin{array}{l}\text { Bolivia and } \\
\text { Ghana }\end{array}$ & $\begin{array}{l}\text { Health education } \\
\text { (2) }\end{array}$ & Low & $\begin{array}{c}-0.07(-0.18 ; \\
0.03)\end{array}$ \\
\hline \multicolumn{9}{|c|}{ Any vaccination coverage } \\
\hline $\begin{array}{l}\text { Conditional } \\
\text { cash transfer }\end{array}$ & 1 & Cross-sectional & Only one study & - & Peru & $\begin{array}{l}\text { Preventive health } \\
\quad \text { visits (1) }\end{array}$ & Low & $\begin{array}{l}0.22(0.12 ; \\
0.32)\end{array}$ \\
\hline $\begin{array}{l}\text { Unconditional } \\
\text { microcredit }\end{array}$ & 1 & Cross-sectional & Only one study & - & Pakistan & - & Low & $\begin{array}{l}0.08(-0.00 ; \\
0.17)\end{array}$ \\
\hline $\begin{array}{l}\text { Conditional } \\
\text { microcredit }\end{array}$ & 2 & $\begin{array}{c}\text { Cluster RCT/ } \\
\text { Cohort }\end{array}$ & $\begin{array}{c}\text { Analysis of CRCT does not } \\
\text { account for clustering }\end{array}$ & Inconsistent & $\begin{array}{c}\text { Bolivia and } \\
\text { Ghana }\end{array}$ & $\begin{array}{l}\text { Health education } \\
\text { (2) }\end{array}$ & Low & $\begin{array}{c}0.06(-0.21 ; \\
0.34)\end{array}$ \\
\hline \multicolumn{9}{|c|}{ Full vaccination coverage } \\
\hline $\begin{array}{l}\text { Unconditional } \\
\text { cash transfer }\end{array}$ & 1 & Cluster RCT & Study not published yet & - & Zimbabwe & - & Low & $\begin{array}{l}0.03(-0.04 ; \\
0.10)\end{array}$ \\
\hline $\begin{array}{l}\text { Conditional } \\
\text { cash transfer }\end{array}$ & 4 & $\begin{array}{l}\text { RCT/Cluster } \\
\text { RCT }\end{array}$ & $\begin{array}{l}\text { Different age groups } \\
\qquad(<2 y \text { and }<5 y)\end{array}$ & $\begin{array}{l}\text { Consistent, all } \\
\text { studies show } \\
\text { benefit }\end{array}$ & $\begin{array}{l}\text { Nicaragua, } \\
\text { Bangladesh, } \\
\text { Zimbabwe }\end{array}$ & $\begin{array}{l}\text { Immunization } \\
\text { and preventive } \\
\text { health visits (3) }\end{array}$ & Moderate & $\begin{array}{l}0.05(-0.01 ; \\
0.10)\end{array}$ \\
\hline
\end{tabular}


were conditional on children attending preventive healthcare visits that included vaccination (Table 4). However, moderate quality evidence compiled from four studies suggests that conditional transfer programs may increase coverage of full, age-appropriate vaccination $(\mathrm{MD}=0.05$; CI: -0.01 to 0.10 ), but this pooled estimate is not statistically significant (Figure 3). Estimates of the vaccination coverage effects of unconditional cash transfer or unconditional microcredit programs, or of conditional voucher schemes, are based only on single studies, some of which were published as non-peerreviewed reports.

Evidence of effect of financial incentives on health care use The pooled analysis of five studies evaluating the impact of conditional cash transfer programs on the prevalence of preventive health care use by children shows an average $14 \%$ net increase among program participants compared to non-participants ( $\mathrm{MD}=0.14 ; \mathrm{CI}:-0.00$ to 0.29 ) (Figure 4). The evidence is inconsistent across studies however, even though the financial incentives in four of the five programs were conditional on preventive health visit attendance, and the overall quality of this evidence is low given the variability in study designs, and because only one study was reported in a peer-reviewed publication (Table 5). Even more pronounced effects were observed for user fee removal on the prevalence $(\mathrm{MD}=0.33$; $\mathrm{CI}: 0.24$ to 0.43 ) and on the frequency ( $\mathrm{MD}=0.99$; $\mathrm{CI}$ : 0.71 to 1.27 ) (Table 5) of curative health care use, but the overall quality of the evidence for these effects was also low, with the pooled estimates based on only two studies each, none of which were randomized. Large and statistically significant effects of user fee removal on the frequency of other types of child health care visits were also shown in several individual studies, but these single study estimates yield low quality evidence only.

\section{Evidence of effect of financial incentives on diarrhoea management}

The overall quality of evidence for the effect of financial incentive programs on diarrhoea management outcomes was low, with only single studies of unconditional or conditional microcredit programs reporting on the use of oral rehydration solutions or on care-seeking during diarrhoea (Table 6). Two studies of conditional microcredit programs reported on the practice of continuing child feeding during diarrhoea, with the pooled estimate suggesting no effect of this type of financial incentive on this outcome (Table 6) despite the conditionality of mothers' attendance of health and nutrition education sessions to qualify for microcredit in both studies.

\section{Evidence of effect of financial incentives on coverage of other preventive health practices}

All available evidence for the effects of financial incentives on other preventive health practices come from randomized or cluster randomized studies of unconditional or conditional cash transfer programs (Table 7). However, only single studies report on deworming and iron supplementation, yielding low quality evidence for these outcomes. Moderate quality evidence pooled from two randomized studies suggests that conditional cash transfer programs may increase the coverage of vitamin A supplementation $(\mathrm{MD}=0.16$; $\mathrm{CI}$ : -0.01 to 0.34 ), but this pooled effect estimate is not statistically

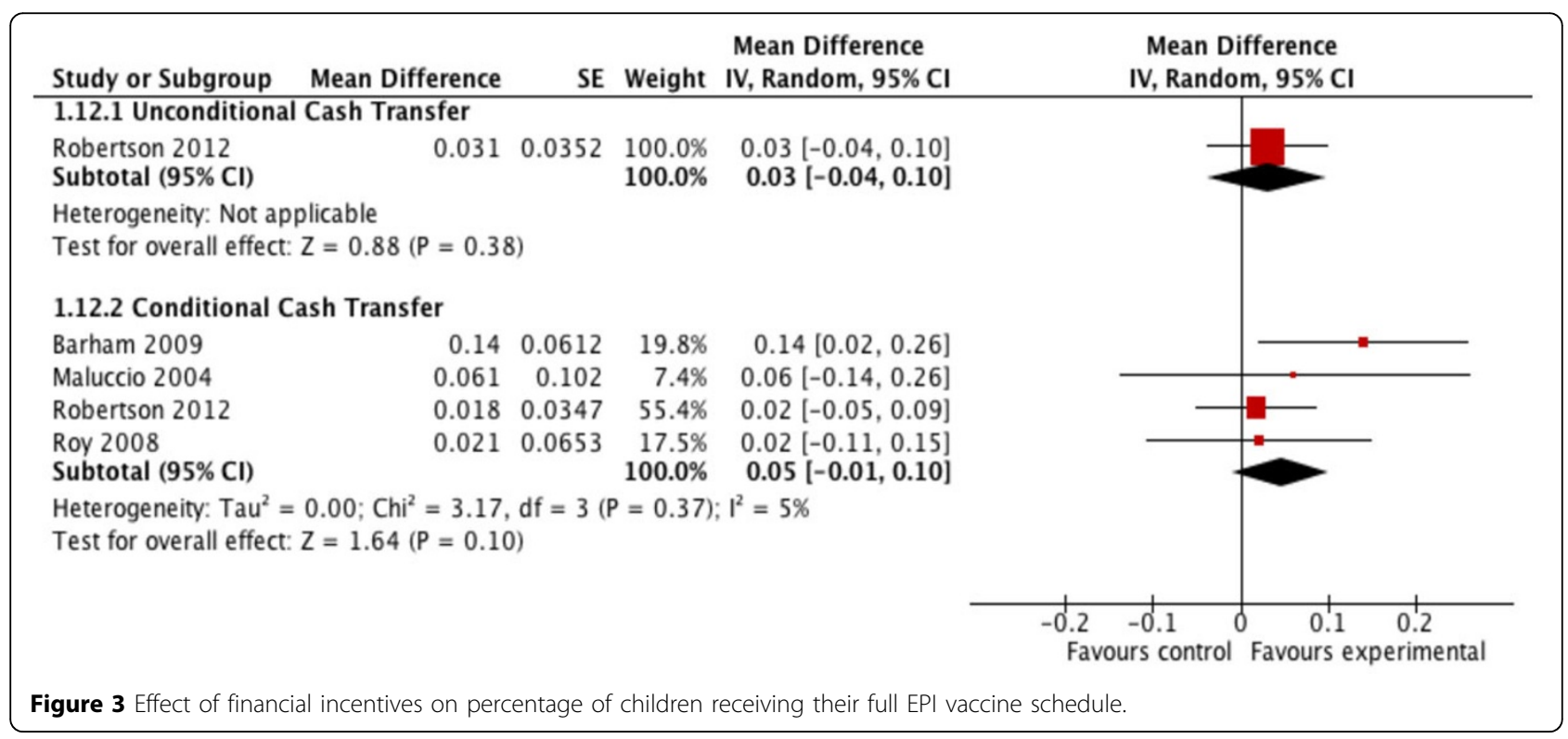


significant (Table 7). The conditionality attached to only one of the two conditional cash transfer programs was health-related, but this conditionality was not monitored.

\section{Discussion}

The apparent appeal of financial incentives is based in part on the underlying assumption that these programs will impact child health. Because there were indications of impacts on some child health outcomes [18], we hypothesized that improved access to health care and increases in coverage of child health interventions must be important components of the pathway from the implementation of financial incentive programs to child health gains. However, our main finding is that there is no high or moderate quality evidence to support this hypothesis. Our results reveal that the evidence for an impact of financial incentive programs on the coverage of a broad range of health interventions among children under five years is generally limited and of low quality. Although evidence on a few specific outcomes may be at maximum moderate, there is only low quality evidence of an effect of financial incentives on the groups of outcomes studied: breastfeeding practices, preventive deworming, health care use in case of illness and preventative health care use.

Reduction or elimination of user fees is one of the few interventions that had very large effects in the use of health services. Although the quality of the evidence is also low, the pronounced effects that were observed for user fee removal on health care use deserves attention. Nevertheless, it should be noted that one study observed a negative effect of generalized user fee removal policies on service use by children and pregnant women [15]. Such effect may be explained by difficulties of the health services in meeting increased demand, and further research is needed to clarify this association.

The role of conditionalities is one of the most important aspects to be addressed when evaluating the impact of financial incentive programs on health. Even in the limited number of studies in our review, it appears that conditioning financial incentives on health-related behaviors significantly influences program effect. It is challenging to attribute the health effects of conditional financial incentive programs to the monetary component because, theoretically, conditionality may be 
Table 5 Quality assessment of effect estimates of financial incentives on coverage of child health care use

\begin{tabular}{|c|c|c|c|c|c|c|c|c|}
\hline Intervention & $\begin{array}{l}\text { No. of } \\
\text { studies }\end{array}$ & Design & Limitations & Consistency & $\begin{array}{c}\text { Generalizability } \\
\text { to population } \\
\text { of interest }\end{array}$ & $\begin{array}{l}\text { Conditionalities } \\
\text { related to } \\
\text { outcome (no. of } \\
\text { studies) } \\
\end{array}$ & $\begin{array}{c}\text { Overall } \\
\text { quality } \\
\text { of } \\
\text { evidence }\end{array}$ & $\begin{array}{c}\text { Mean } \\
\text { difference } \\
(95 \% \mathrm{Cl})\end{array}$ \\
\hline \multicolumn{9}{|c|}{ Preventive health care use } \\
\hline $\begin{array}{l}\text { Unconditional } \\
\text { cash transfer }\end{array}$ & 1 & Cluster RCT & Only one study & - & Ecuador & $\begin{array}{l}\text { Preventive health } \\
\text { visits, but } \\
\text { conditionality } \\
\text { was not } \\
\text { implemented (1) }\end{array}$ & Low & $\begin{array}{l}0.01(-0.10 ; \\
0.12)\end{array}$ \\
\hline $\begin{array}{l}\text { Conditional } \\
\text { cash transfer }\end{array}$ & 5 & $\begin{array}{l}\text { Cluster RCT/Cohort/ } \\
\text { Longitudinal panel/ } \\
\text { Cross-sectional }\end{array}$ & $\begin{array}{c}\text { Variability in study } \\
\text { design, reporting } \\
\text { periods and only } \\
\text { one peer-reviewed } \\
\text { study }\end{array}$ & Inconsistent & $\begin{array}{l}\text { Chile, Colombia, } \\
\text { Nicaragua, Peru }\end{array}$ & $\begin{array}{l}\text { Preventive health } \\
\text { visits (4) }\end{array}$ & Low & $\begin{array}{l}0.14(-0.00 ; \\
0.29)\end{array}$ \\
\hline $\begin{array}{l}\text { Unconditional } \\
\text { microcredit }\end{array}$ & 1 & Cross-sectional & Only one study & - & Bangladesh & - & Low & $\begin{array}{l}0.04(0.02 ; \\
0.06)\end{array}$ \\
\hline $\begin{array}{l}\text { Conditional } \\
\text { voucher }\end{array}$ & 1 & Cluster RCT & $\begin{array}{c}\text { Only one study and } \\
\text { shorter reporting } \\
\text { period }\end{array}$ & - & Honduras & $\begin{array}{l}\text { Preventive health } \\
\text { visits (1) }\end{array}$ & Low & $\begin{array}{l}0.16(0.13 ; \\
0.18)\end{array}$ \\
\hline \multicolumn{9}{|c|}{ Curative health care use } \\
\hline $\begin{array}{l}\text { Conditional } \\
\text { cash transfer }\end{array}$ & 1 & Cross-sectional & Only one study & - & Peru & $\begin{array}{c}\text { Preventive health } \\
\text { visits (1) }\end{array}$ & Low & $\begin{array}{l}0.22(0.12 ; \\
0.32)\end{array}$ \\
\hline $\begin{array}{l}\text { Unconditional } \\
\text { microcredit }\end{array}$ & 2 & Cross-sectional & $\begin{array}{l}\text { Reverse causality } \\
\text { possible in all studies }\end{array}$ & Consistent & $\begin{array}{l}\text { Bangladesh and } \\
\text { Pakistan }\end{array}$ & - & Low & $\begin{array}{l}0.10(0.07 ; \\
0.13)\end{array}$ \\
\hline $\begin{array}{l}\text { User fee } \\
\text { removal }\end{array}$ & 2 & $\begin{array}{l}\text { Cross-sectional } \\
\text { /Before and after } \\
\text { design using } \\
\text { administrative data }\end{array}$ & $\begin{array}{l}\text { Individual-level data } \\
\text { in one study and } \\
\text { clinic-level data in } \\
\text { the other, neither } \\
\text { experimental }\end{array}$ & $\begin{array}{l}\text { Consistent, } \\
\text { both studies } \\
\text { show } \\
\text { benefit }\end{array}$ & Rwanda, Sudan & - & Low & $\begin{array}{l}0.33(0.24 ; \\
0.43)\end{array}$ \\
\hline \multicolumn{9}{|c|}{ Health care use } \\
\hline $\begin{array}{l}\text { Conditional } \\
\text { cash transfer }\end{array}$ & 1 & Longitudinal panel & Only one study & - & Brazil & $\begin{array}{c}\text { Preventive health } \\
\text { visits (1) }\end{array}$ & Low & $\begin{array}{l}0.04(-0.02 ; \\
0.10)\end{array}$ \\
\hline \multicolumn{9}{|c|}{ Preventive health care visits } \\
\hline $\begin{array}{l}\text { Conditional } \\
\text { cash transfer }\end{array}$ & 1 & Cohort & Only one study & - & Jamaica & $\begin{array}{c}\text { Preventive health } \\
\text { visits (1) }\end{array}$ & Low & $\begin{array}{l}0.38(0.15 \\
0.62)\end{array}$ \\
\hline $\begin{array}{l}\text { User fee } \\
\text { removal }\end{array}$ & 1 & $\begin{array}{l}\text { Before and after } \\
\text { design using } \\
\text { administrative data }\end{array}$ & Only one study & - & South Africa & - & Low & $\begin{array}{c}-0.03(-0.18 \\
0.13)\end{array}$ \\
\hline \multicolumn{9}{|c|}{ Curative health care visits } \\
\hline $\begin{array}{l}\text { User fee } \\
\text { removal }\end{array}$ & 2 & $\begin{array}{l}\text { Before and after } \\
\text { design using } \\
\text { administrative data }\end{array}$ & $\begin{array}{l}\text { No control group, } \\
\text { one study limits the } \\
\text { outcome to visits } \\
\text { due to malaria only }\end{array}$ & $\begin{array}{l}\text { Consistent, } \\
\text { both studies } \\
\text { show } \\
\text { benefit }\end{array}$ & Niger and Kenya & - & Low & $\begin{array}{l}0.99(0.71 ; \\
1.27)\end{array}$ \\
\hline \multicolumn{9}{|c|}{ New health care visits } \\
\hline $\begin{array}{l}\text { User fee } \\
\text { removal }\end{array}$ & 1 & $\begin{array}{c}\text { Before and after } \\
\text { design using } \\
\text { administrative data }\end{array}$ & Only one study & - & Uganda & - & Low & $\begin{array}{l}0.27(0.18 ; \\
0.37)\end{array}$ \\
\hline \multicolumn{9}{|c|}{ Follow-up health care visits } \\
\hline $\begin{array}{l}\text { User fee } \\
\text { removal }\end{array}$ & 1 & $\begin{array}{c}\text { Before and after } \\
\text { design using } \\
\text { administrative data }\end{array}$ & Only one study & - & Uganda & - & Low & $\begin{array}{l}0.81(0.73 ; \\
0.90)\end{array}$ \\
\hline \multicolumn{9}{|c|}{ Health care visits } \\
\hline $\begin{array}{l}\text { Conditional } \\
\text { cash transfer }\end{array}$ & 1 & Cluster RCT & Only one study & - & Mexico & $\begin{array}{l}\text { Preventive health } \\
\text { visits (1) }\end{array}$ & Low & $\begin{array}{l}-0.01(-0.02 \\
-0.00)\end{array}$ \\
\hline $\begin{array}{l}\text { User fee } \\
\text { removal }\end{array}$ & 1 & $\begin{array}{l}\text { Before and after } \\
\text { design using } \\
\text { administrative data }\end{array}$ & Clinic-level data & - & Uganda & - & Low & $\begin{array}{l}0.20(0.10 ; \\
0.29)\end{array}$ \\
\hline
\end{tabular}


Table 6 Quality assessment of effect estimates of financial incentives on management of diarrhoeal disease

\begin{tabular}{|c|c|c|c|c|c|c|c|c|}
\hline Intervention & $\begin{array}{l}\text { No. of } \\
\text { studies }\end{array}$ & Design & Limitations & Consistency & $\begin{array}{l}\text { Generalizability } \\
\text { to population } \\
\text { of interest }\end{array}$ & $\begin{array}{c}\text { Conditionalities } \\
\text { related to } \\
\text { outcome (no. of } \\
\text { studies) }\end{array}$ & $\begin{array}{c}\text { Overall } \\
\text { quality } \\
\text { of } \\
\text { evidence }\end{array}$ & $\begin{array}{c}\text { Mean } \\
\text { difference } \\
(95 \% \mathrm{Cl})\end{array}$ \\
\hline \multicolumn{9}{|c|}{ ORS use } \\
\hline $\begin{array}{l}\text { Unconditional } \\
\text { microcredit }\end{array}$ & 1 & $\begin{array}{c}\text { Cross- } \\
\text { sectional }\end{array}$ & Only one study & - & Pakistan & - & Low & $\begin{array}{c}0.02(-0.02 ; \\
0.05)\end{array}$ \\
\hline $\begin{array}{l}\text { Conditional } \\
\text { microcredit }\end{array}$ & 1 & Cohort & Only one study & - & Ghana & $\begin{array}{l}\text { Health and nutrition } \\
\text { education (1) }\end{array}$ & Low & $\begin{array}{l}0.65(0.53 ; \\
0.77)\end{array}$ \\
\hline \multicolumn{9}{|c|}{ Continued feeding } \\
\hline $\begin{array}{l}\text { Conditional } \\
\text { microcredit }\end{array}$ & 2 & $\begin{array}{l}\text { Cluster } \\
\text { RCT/ } \\
\text { Cohort }\end{array}$ & $\begin{array}{l}\text { Only two studies; analysis of } \\
\text { CRCT does not account for } \\
\text { clustering }\end{array}$ & Consistent & $\begin{array}{l}\text { Bolivia and } \\
\text { Ghana }\end{array}$ & $\begin{array}{l}\text { Health and nutrition } \\
\text { education (2) }\end{array}$ & Low & $\begin{array}{l}0.03(-0.07 \\
0.13)\end{array}$ \\
\hline \multicolumn{9}{|c|}{ Care-seeking } \\
\hline $\begin{array}{l}\text { Conditional } \\
\text { cash transfer }\end{array}$ & 1 & $\begin{array}{l}\text { Cluster } \\
\text { RCT }\end{array}$ & $\begin{array}{l}\text { Only one study; outcome not } \\
\text { limited to diarrhea, includes } \\
\text { consultations for other diseases }\end{array}$ & - & Nicaragua & $\begin{array}{c}\text { Children's health } \\
\text { service attendance, } \\
\text { but not monitored } \\
\text { (1) }\end{array}$ & Low & $\begin{array}{c}0.03(-0.03 \\
0.09)\end{array}$ \\
\hline
\end{tabular}

confounding this effect and also because programs are not designed to allow its evaluations to separate the effects.

Among the studies included in our review, in most cases the conditionality is related to participation in health activities that are directly related to the health outcome of interest. It has been previously noted that these health education or knowledge-transfer activities do increase coverage of interventions [1], therefore it is not surprising to notice that in our results all the positive effects observed for the group of breastfeeding outcomes, for example, come from programs that were

Table 7 Quality assessment of effect estimates of financial incentives on coverage of other preventive health interventions

\begin{tabular}{|c|c|c|c|c|c|c|c|c|}
\hline Intervention & $\begin{array}{l}\text { No. of } \\
\text { studies }\end{array}$ & Design & Limitations & Consistency & $\begin{array}{l}\text { Generalizability } \\
\text { to population } \\
\text { of interest }\end{array}$ & $\begin{array}{l}\text { Conditionalities } \\
\text { related to outcome } \\
\text { (no. of studies) }\end{array}$ & $\begin{array}{l}\text { Overall } \\
\text { quality } \\
\text { of } \\
\text { evidence }\end{array}$ & $\begin{array}{c}\text { Mean } \\
\text { difference } \\
(95 \% \mathrm{Cl})\end{array}$ \\
\hline \multicolumn{9}{|c|}{ Preventive deworming } \\
\hline $\begin{array}{l}\text { Unconditional } \\
\text { cash transfer }\end{array}$ & 1 & $\begin{array}{l}\text { Cluster } \\
\text { RCT }\end{array}$ & Only one study & - & Ecuador* & $\begin{array}{l}\text { Preventive health } \\
\text { visits, but } \\
\text { conditionality was not } \\
\text { implemented (1) }\end{array}$ & Low & $\begin{array}{l}0.08(0.01 ; \\
0.15)\end{array}$ \\
\hline $\begin{array}{l}\text { Conditional } \\
\text { cash transfer }\end{array}$ & 1 & $\begin{array}{l}\text { Cluster } \\
\text { RCT }\end{array}$ & Only one study & - & Nicaragua** & $\begin{array}{l}\text { Preventive health } \\
\text { visits, but condition } \\
\text { was not monitored } \\
\text { (1) }\end{array}$ & Low & $\begin{array}{l}0.08(0.00 ; \\
0.16)\end{array}$ \\
\hline \multicolumn{9}{|c|}{ Vitamin A supplemention } \\
\hline $\begin{array}{l}\text { Unconditional } \\
\text { cash transfer }\end{array}$ & 1 & $\begin{array}{l}\text { Cluster } \\
\text { RCT }\end{array}$ & Only one study & - & Ecuador* & $\begin{array}{l}\text { Preventive health } \\
\text { visits, but } \\
\text { conditionality was not } \\
\text { implemented (1) }\end{array}$ & Low & $\begin{array}{l}0.01(-0.03 \\
0.04)\end{array}$ \\
\hline $\begin{array}{l}\text { Conditional } \\
\text { cash transfer }\end{array}$ & 2 & $\begin{array}{l}\text { RCT } \\
\text { /Cluster } \\
\text { RCT }\end{array}$ & $\begin{array}{l}\text { Study in Nicaragua included } \\
\text { three different CCT } \\
\text { interventions but all were } \\
\text { analyzed together }\end{array}$ & $\begin{array}{l}\text { Consistent, } \\
\text { both studies } \\
\text { show } \\
\text { benefit }\end{array}$ & $\begin{array}{l}\text { Bangladesh* and } \\
\text { Nicaragua** }\end{array}$ & $\begin{array}{c}\text { Preventive health } \\
\text { visits, but condition } \\
\text { was not monitored } \\
\text { (1) }\end{array}$ & Moderate & $\begin{array}{l}0.16(-0.01 \\
0.34)\end{array}$ \\
\hline \multicolumn{9}{|c|}{ Iron supplementation } \\
\hline $\begin{array}{l}\text { Unconditional } \\
\text { cash transfer }\end{array}$ & 1 & $\begin{array}{l}\text { Cluster } \\
\text { RCT }\end{array}$ & Only one study & - & Ecuador* & $\begin{array}{l}\text { Preventive health } \\
\text { visits, but } \\
\text { conditionality was not } \\
\text { implemented (1) }\end{array}$ & Low & $\begin{array}{c}0.01(-0.03 \\
0.05)\end{array}$ \\
\hline $\begin{array}{l}\text { Conditional } \\
\text { cash transfer }\end{array}$ & 1 & $\begin{array}{l}\text { Cluster } \\
\text { RCT }\end{array}$ & Only one study & - & Nicaragua** & $\begin{array}{l}\text { Children's health } \\
\text { service attendance (1) }\end{array}$ & Low & $\begin{array}{c}0.36(0.25 ; \\
0.47)\end{array}$ \\
\hline
\end{tabular}

* 12-month reporting period, ** 4-month reporting period 
conditional on women's participation in health and nutritional education activities, all of which had a strong emphasis on breastfeeding promotion (Table 3). Similarly, the effect of conditional transfer programs on the coverage of full, age-appropriate vaccination, even though not statistically significant, is based on the pooled results of four studies, three of which were conditional on the participant maintaining vaccines up to date.

To strengthen this point, four of the five studies evaluating the impact of conditional cash transfer programs on preventive health care use were conditional on children attending preventive health care services routinely. Under such circumstances, it may be surprising that the pooled analysis yielded only a moderate $14 \%$ net increase among program participants. This difficulty in interpreting results of conditional financial incentives has been noted in a previous discussion about financial incentive programs [2], and indeed, isolating the effects of financial and non-financial program components is a daunting but necessary task that should be incorporated in the design of future evaluations of such programs.

The quantitative evidence for an effect of financial incentives and policies on the coverage of child health interventions presented here does not support the positive findings of earlier qualitative assessments of such programs $[18,35]$. Because the evidence is currently limited and of low quality, we plan to conduct systematic updates of this analysis as new studies and evaluations of such interventions become available. In addition, a similar exercise to systematically evaluate the evidence of the impact of such programs on other aspects of child health and development, such as morbidity and mortality, is warranted.

\section{Additional material}

Additional File 1: Electronic search strategy for MEDLINE, EMBASE and AMED databases.

Additional File 2: Abstracted data from all 25 studies included in the quantitative data synthesis.

Additional File 3: Forest plots for all outcomes.

\section{Competing interests}

The authors declare that they have no competing interests.

\section{Authors' contributions}

$Z A B$ conceived of the study; DGB, PA, KW and ZAB wrote the protocol; KW conducted the literature searches, and abstracted the data with PA and DGB. KW and LL assessed study quality, with DGB and MFG resolving discrepancies; DGB and MFG analyzed the data and wrote the first draft of the manuscript; all authors revised the draft and approved the final manuscript.

\section{Declaration}

The publication costs for this supplement were funded by a grant from the Bill \& Melinda Gates Foundation to the US Fund for UNICEF (grant 43386 to
"Promote evidence-based decision making in designing maternal, neonatal, and child health interventions in low- and middle-income countries"). The Supplement Editor is the principal investigator and lead in the development of the Lives Saved Tool (LiST), supported by grant 43386. He declares that he has no competing interests.

This article has been published as part of BMC Public Health Volume 13 Supplement 3, 2013: The Lives Saved Tool in 2013: new capabilities and applications. The full contents of the supplement are available online at http://www.biomedcentral.com/bmcpublichealth/supplements/13/S3.

\section{Authors' details}

${ }^{1}$ Centre for Global Child Health, The Hospital for Sick Children, Toronto, ON, Canada. ${ }^{2}$ Dalla Lana School of Public Health, University of Toronto, Toronto, ON, Canada. ${ }^{3}$ Department of Paediatrics, University of Toronto, Toronto, ON, Canada. ${ }^{4}$ Division of Women and Child Health, Aga Khan University Hospital, Karachi, Pakistan

Published: 17 September 2013

\section{References}

1. Chopra M, Sharkey A, Dalmiya N, Anthony D, Binkin N: Strategies to improve health coverage and narrow the equity gap in child survival, health, and nutrition. Lancet 2012, 380(9850):1331-1340.

2. World Health Organization: Public health agencies and cash transfer programmes : making the case for greater involvement. Geneva: World Health Organization; 2011.

3. Hamad R, Fernald LC: Microcredit participation and nutrition outcomes among women in Peru. J Epidemiol Community Health 2012, 66(6):e1.

4. Norwood C: Women, microcredit and family planning practices: a case study from rural Ghana. J Asian Afr Stud 2011, 46(2):169-183.

5. Gautam Hazarika, B G-K: Household Access to Microcredit and Children's Food Security in Rural Malawi: A Gender Perspective. 2008, 1-18.

6. Amouzou A, Habi O, Bensaid K: Reduction in child mortality in Niger: a Countdown to 2015 country case study. Lancet 2012, 380(9848):1169-1178.

7. Morris SS, Flores R, Olinto P, Medina JM: Monetary incentives in primary health care and effects on use and coverage of preventive health care interventions in rural Honduras: cluster randomised trial. Lancet 2004, 364(9450):2030-2037.

8. Paxson C, Schady N: Does Money Matter? The Effects of Cash Transfers on Child Development in Rural Ecuador. Economic Development and Cultural Change 2010, 59(1):187-229.

9. Paes-Sousa R, Santos LM, Miazaki ES: Effects of a conditional cash transfer programme on child nutrition in Brazil. Bulletin of the World Health Organization 2011, 89(7):496-503.

10. Maluccio J, Flores R: Impact Evaluation of a Conditional Cash Transfer Program: The Nicaraguan. Red de Protección Social", Fund Discussion Paper 2004, 184.

11. Aguero J, Carter MR, Woolard I: The impact of unconditional cash transfers on nutrition: The South African Child Support Grant. 2007.

12. Fernald LC, Hidrobo M: Effect of Ecuador's cash transfer program (Bono de Desarrollo Humano) on child development in infants and toddlers: a randomized effectiveness trial. Soc Sci Med 2011, 72(9):1437-1446.

13. Attanasio O, Meghir C, Schady N: Mexico's conditional cash transfer programme. Lancet 2010, 375(9719):980-981, author reply.

14. Fernald LC, Gertler PJ, Neufeld LM: 10-year effect of Oportunidades, Mexico's conditional cash transfer programme, on child growth, cognition, language, and behaviour: a longitudinal follow-up study. Lancet 2009, 374(9706):1997-2005.

15. Wilkinson D, Gouws E, Sach M, Karim SS: Effect of removing user fees on attendance for curative and preventive primary health care services in rural South Africa. Bulletin of the World Health Organization 2001, 79(7):665-671.

16. Burgert CR, Bigogo G, Adazu K, Odhiambo F, Buehler J, Breiman RF, Laserson K, Hamel MJ, Feikin DR: Impact of implementation of free highquality health care on health facility attendance by sick children in rural western Kenya. Trop Med Int Health 2011, 16(6):711-720.

17. Palmer N, Mueller DH, Gilson L, Mills A, Haines A: Health financing to promote access in low income settings-how much do we know? Lancet 2004, 364(9442):1365-1370. 
18. Lagarde $M$, Haines A, Palmer $\mathrm{N}$ : Conditional cash transfers for improving uptake of health interventions in low- and middle-income countries: a systematic review. JAMA 2007, 298(16):1900-1910.

19. Bryant JH: Kenya's cash transfer program: protecting the health and human rights of orphans and vulnerable children. Health Hum Rights 2009, 11(2):65-76.

20. Ahmed AU, Shams Y: Nutritional effects of cash versus commodity-based public works programs. Bangladesh Food Policy Project Manuscript 63. Washington, DC: International Food Policy Research Institute. International Food Policy Research Institute 1994.

21. Amin R, St Pierre M, Ahmed A, Haq R: Integration of an essential services package (ESP) in child and reproductive health and family planning with a micro-credit program for poor women: experience from a pilot project in rural Bangladesh. World Development 2001, 29(9):1611-1621.

22. Roy SK, Bilkes F, Islam K, Ara G, Tanner P, Wosk I, Rahman AS, Chakraborty B, Jolly SP, Khatun W: Impact of pilot project of Rural Maintenance Programme (RMP) on destitute women: CARE, Bangladesh. Food and nutrition bulletin 2008, 29(1):67-75.

23. Montgomery $\mathrm{H}$, Weiss J: Can Commercially-oriented Microfinance Help Meet the Millennium Development Goals? Evidence from Pakistan. World Development 2011, 39(1):87-109.

24. Gopalan SS, Durairaj V: Addressing maternal healthcare through demand side financial incentives: experience of Janani Suraksha Yojana program in India. BMC Health Serv Res 2012, 12:319.

25. Saude Md: Avaliacao do Programa Bolsa-Alimentacao. Brasilia: Government of Brazil; 2005, 1-118.

26. Galasso E: Alleviating extreme poverty in Chile: the short term effects of Chile Solidario. Estudios de Economía 2001, 38(1):102.

27. Wilkinson D, Sach ME, Abdool Karim SS: Examination of attendance patterns before and after introduction of South Africa's policy of free health care for children aged under 6 years and pregnant women. Bmj 1997, 314(7085):940-941.

28. Cash transfers for children-investing into the future. Lancet 2009, 373(9682):2172.

29. Oliver A, Brown LD: A consideration of user financial incentives to address health inequalities. J Health Polit Policy Law 2012, 37(2):201-226.

30. Oliver A: Can financial incentives improve health equity? Bmj 2009, 339 b3847.

31. Fernald LC, Gertler PJ, Neufeld LM: Role of cash in conditional cash transfer programmes for child health, growth, and development: an analysis of Mexico's Oportunidades. Lancet 2008, 371(9615):828-837.

32. Barber SL, Gertler PJ: Empowering women to obtain high quality care: evidence from an evaluation of Mexico's conditional cash transfer programme. Health Policy Plan 2009, 24(1):18-25.

33. MkNelly B, Dunford C: Impact of credit with education on mothers and their young children's nutrition: Lower Pra Rural Bank credit with education program in Ghana. Freedom from Hunger Research Paper 1998.

34. MkNelly B, Dunford C: Impact of credit with education on mothers and their young children's nutrition: CRECER credit with education program in Bolivia. Freedom from Hunger Research Paper 1999.

35. Lagarde M, Haines A, Palmer N: The impact of conditional cash transfers on health outcomes and use of health services in low and middle income countries. Cochrane Database Syst Rev 2009, , 4: CD008137.

36. Lagarde M, Palmer N: The impact of user fees on access to health services in low- and middle-income countries. Cochrane Database Syst Rev 2011, 4:CD009094.

37. Lagarde M, Palmer N: The impact of user fees on health service utilization in low- and middle-income countries: how strong is the evidence? Bulletin of the World Health Organization 2008, 86(11):839-848.

38. Walker N, Fischer-Walker C, Bryce J, Bahl R, Cousens S: Standards for CHERG reviews of intervention effects on child survival. Int J Epidemiol 2010, 39(Suppl 1):i21-31.

39. Gertler P: Do conditional cash transfers improve child health? Evidence from PROGRESA's control randomized experiment. The American Economic Review 2004, 94(2):336-341.

40. Abdu Z, Mohammed Z, Bashier I, Eriksson B: The impact of user fee exemption on service utilization and treatment seeking behaviour: the case of malaria in Sudan. The International journal of health planning and management 2004, 19(Suppl 1):S95-106.
41. Pitt MM, Khandker SR, Chowdhury OH, Millimet DL: Credit programs for the poor and the health status of children in rural bangladesh*. International Economic Review 2003, 44(1):87-118.

42. Lagarde M, Barroy $H$, Palmer N: Assessing the effects of removing user fees in Zambia and Niger. J Health Serv Res Policy 2012, 17(1):30-36.

43. Attanasio O, Gomez LC, Heredia P, Vera-Hernandez M: The short-term impact of a conditional cash subsidy on child health and nutrition in Colombia. Report Summary: Familias 2005, 3.

44. Barham T, Maluccio JA: Eradicating diseases: The effect of conditional cash transfers on vaccination coverage in rural Nicaragua. Journal of Health Economics 2009, 28(3):611-621.

45. Gertler P, Boyce S: An Experiment in Incentive-based Welfare: The impact of Progresa on health in Mexico. University of California, Berkeley 2001, 30-37.

46. Levin A, Rahman MA, Quayyum Z, Routh S: The demand for child curative care in two rural thanas of Bangladesh: effect of income and women\&apos;s employment. The International Journal of Health Planning and Management 2001, 16(3):179-194.

47. Levy D, Ohls J: Evaluation of Jamaica's PATH program: final report. Report prepared 2007.

48. Macours K, Schady N, Vakis R: Cash Transfers, Behavioral Changes, and the Cognitive Development of Young Children: Evidence from a Randomized Experiment. Policy Research Working Paper 2008, 4759.

49. Perova E, Vakis R: Welfare impacts of the "Juntos" Program in Peru: Evidence from a non-experimental evaluation. The World Bank 2009

50. Robertson L, Mushati P, Eaton JW, Dumba L, Mavise G, Makoni M, Schumacher C, Crea T, Monasch R, Sherr L, Garnett GP, Nyamukapa C, Gregson S: Effects of unconditional and conditional cash transfers on child health and development in Zimbabwe: a cluster-randomised trial. Lancet 2013, 381:1283-1292.

51. Smith SC: Village banking and maternal and child health: evidence from Ecuador and Honduras. World Development 2002, 30(4):707-723.

52. Burnham GM, Pariyo G, Galiwango E, Wabwire-Mangen F: Discontinuation of cost sharing in Uganda. Bulletin of the World Health Organization 2004 82(3):187-195.

53. Dhillon RS, Bonds MH, Fraden M, Ndahiro D, Ruxin J: The impact of reducing financial barriers on utilisation of a primary health care facility in Rwanda. Glob Public Health 2012, 7(1):71-86.

doi:10.1186/1471-2458-13-S3-S30

Cite this article as: Bassani et al:: Financial incentives and coverage of child health interventions: a systematic review and meta-analysis. $B M C$ Public Health 2013 13(Suppl 3):S30.

\section{Submit your next manuscript to BioMed Central and take full advantage of:}

- Convenient online submission

- Thorough peer review

- No space constraints or color figure charges

- Immediate publication on acceptance

- Inclusion in PubMed, CAS, Scopus and Google Scholar

- Research which is freely available for redistribution

Submit your manuscript at www.biomedcentral.com/submit
C Biomed Central 